\title{
PULlEUGENOL SEBAGAi SENYAWA PEMBAWA UNTUK TRANSPOR FENOL MENGGUNAKAN METODE POLYMER INCLUSION MEMBRANE (PIM)
}

\author{
Agung Abadi Kiswandono' Dwi Siswanta². Fni Kartika Sar ${ }^{3}$ \\ ${ }^{1}$ Fakultas Kesehatan Masyarakat, Prima University, Medan, Indonesia \\ ${ }^{2}$ Jurusan Kimia, Fakultas Matematika dan Ilmu Pengetahuan Alam \\ Universitas Gadjah Mada, Sekip Utara, Yogyakarta, Indonesia, 55281 \\ ${ }^{3}$ Akademi Analisis Farmasi Al-Islam Yogyakarta \\ 'Email: nane shilaravahoo.com
}

\section{ABSTRACT \\ Polieugenol as Carrier Substances for Transport of Phenol Using the Method of Polymer Inclusions Membrane (PIB)}

\begin{abstract}
Separation of phenol from waste lipud with liputi mumbrane technology mathod of PM (Polymer

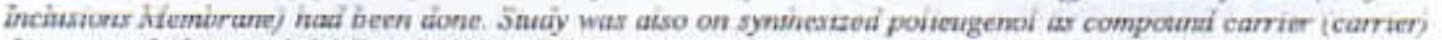
then printed along with DBE and PVC as PIM membrane for the transport of phenol using the PIM method. The resulting of Polieugenol were characterted by H.NMR, FT.DR, TG.DTA and SEM. While the evoluation of membran polieugenol has been done by anatyzing the use of thiversul Testing Machine for tonsile strungth and the number of misring components during the process of transport loss componcht (Maly), Lastly, to krow the physical difforences of the membrane of PIM, the membrane before and after aransport were characterized asing Scuming Electron Micruscopy (SFM) and Fourier Trumsform Enfri-Red (FTIR). The reseurch reaults obtuined

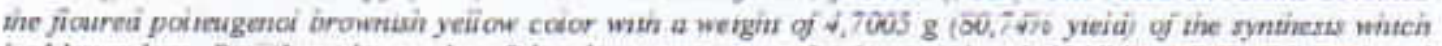
had been done Bused on the resilts of the characterization of poliengenol with H-NMR. FT-IR, TG-DTA and SEM, abtatned the information that there had been die palymerizaticin reaction of argenol formed polieugrabl. Test of phenol with membirane transport of poliengenol indicated that mambrane transpart capabled PLM phenol with average number of 464 . Resuits of the charncterisution of a PAM membrane with SEMI. Universul Tosting Machine and FTIR, indicating the occurrence of PMM membrume morphology changes once used for arangorl of phenol dive to missing of quecies of membname during tranport process.
\end{abstract}

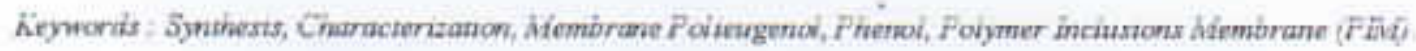

\begin{abstract}
ABSTRAK
Pemisahan fend dan limbah cair dengan teknologi membran cair metode PIM (Polymer Inchusion Afembrane) telah dilakukan. Pada penelitim ini disintesis polienpenol sebagai sernyawn pernbawa (carrier)

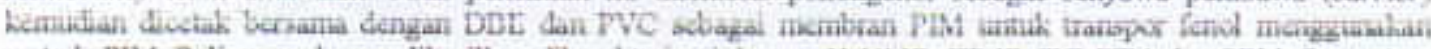
metode PIM. Polieugenol yung dilasillkan dilarakterisasi dengan H-NMR, FT-IR, TG-DTA dan SEM Sementam evaluasi terhadap membran polieugenol dilalakan dengan menganalisis menggunakan Universal Testing Machine untuk mengetahui kast tarik (tensile strength dan jumlah komponen yung hilung ML loss selama proses transpor. Terakhir, untuk menpotahui perbectuan fisik membran PIM, maka membran sebelum dan sessutah transpor dikarakterisasi menggunakan Scanning Electron Microscope (SEM) dan Fouriar Trauform Infra Red (FTIR) Dari penelition ini diperoleh hasil berupa serbuk poliengenol berwarna kaning kcooklatan dengan berat

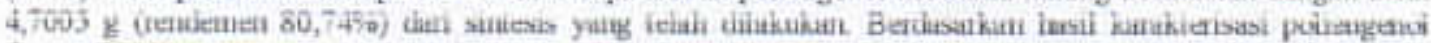
dengan H-NMR, FT-IR, TG-DTA dan SEM, diperoleh informasi bahwa telah teriadi reaksi polimerisasi augenol membentuk polieugenol. Uji transpor fanol dengan membnan polieugenol menuniukian bahwa membran PIM manmp mentranspor fenol dengan jumlah rata - rata $46 \%$. Hasil karakterisasi terhadap membran PIM dengan SEM, Ciniversal Testing Machie dan FTIR, menunjukkan tajadinya perubahan mcrfologi membran PIM setelah đigunakan untuk mentranspor fenol karena adanya spesies membran yung hilang selama ptoses transpot.
\end{abstract}

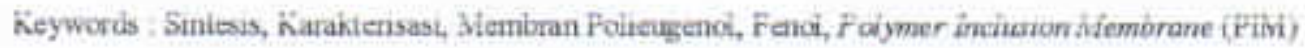




\section{PENDAHULUAN}

Perkembangan teknologi industri yang ditujukan untuk kesejahteraan manusia temyata tidak selalu memberikan dampak yang positif, khususnya bagi lingkungan hidup. Hal ini disebabkan karena sebagian besar bahan - bahan yang digunaikan daiam proses industri termasuik dalam bahan beracun berbahaya. Sisa bahan baku yang tidak digunakan pada akhimya menghasilkan limbah beracun berbahaya yang kemudian dibuang ke lingkungan perairan sekitar. Salah satu limbah beraeun berbahaya yang dihasilkan dari suatu industri adalah fenol, karena beracun dan bersifat korosif terhadap kulit sorta karsinogenik, olch karena itu fonol digolongkan sebagai bahan beracun dan berbahaya (B3). US EPA menglategorikan fenol dalam daftar prioritas senyawa toksilk pencemar daerah perairan (Mortahebet al. 2008).

Limbah senyawa fenol dihasilkan dari limbah cair industri mikroelektronik. industri minyak dan gas, teikstii, kertas, otomotif, pabrik bahan kimia, kayu lapis, farmasi, cat, tekstil, keramik, plastik, dan sebagainya. Senyawa fenol dapat menimbulkan efek kronik bagi organisme dan menyebabkan kematian pada ikan pada konsentrasi yang sangat rendah, yakni 5 - $25 \mathrm{mg} /$. (Alva dan Peyton, 2003). Fenol dapat mengalami bioakumulasi dan biomagnifikasi oleh organisme perairan (akuatik), fenol dapat masuk ke dalam tuhuh melalui air minum dan malianan yang berasal dari organisme akuatik.

Disamping kerugian yang ditimbulkan, fenol merupakan senyawa yang memiliki banyak kegunaan, misalnya sebagai bahan perekat kayu lapis, bahan anestetiica orai dan obat-obatan, seiningga pemulihan fenol dari air limbah merupakan hal yang menarik. Proses penanggulangan dan penanganan limbah industri dalam bentuk senyawa organik fenol menjadi bagian yang sangat penting untuk melindungi dan melestarikan lingkungan. karena limbah yang timbul dapat mengakibatkan pencemaran apabila dibuang begitu saja scbelum mengalami pengolahan.
Fenol dapat dihilangkan dengan beberapa teknik, di antaranya adalah ulsupsi. Meva! $\{2004\}$ telah memisotuan fenol dari air limbah menggunakan batubara muda (lignitic coals) dengan rendemen $43 \%$ - $60 \%$, Moraitopoulos (2009) juga telah memisahan fenol menggunakan karbon aktif, tetapi teknik tersebut umumnya tiảak eikonomis karena membutuhkan bahan serta energi yang besar (Sun et al. 2007).

Cara hain memisahkan fenol adalah dengan membran eair. Teknologi membran telah berkembang dengan pesat dalam beberapa dekade terakhir ini karenamemiliki berbagai keunggulan baik secara teknik maupun secara ekonomi, schingga sering kali digunakan dalam proses - proses pemisahan maupun pemumian baik untul skals industri maupun penelitian di laboraturium. Keunggulan tersebut dikarenakan dalam pemisahan dengan membran tidak membutuhkan zat kimia tambahan dan juga kebutuhan energinya sangat minimum, sedernana, praiktis dan mudah dilakukan.

Drapala et al. (2001) menggunakan membran eair untuk ckstraksi peptida, Titus et al. (2005) untuk Ektrasi 17ß-estradiol dari ginial. susu, dan urin. Membran cair yang dipakai dalam penelitian Garea et.al. (1983), Cichy \& Szymanowski (2002) dapat memisahan senyawa fenol dengan metode SLM menggunakan eampuran kerosin dan cyanes 923 sedanglan hasil elsperimen Kusumastuti (2007) menunjukkan bahwa lebih dari $90 \%$ fenol dapat dipulihkan dari air limbah dengan menggunakan membran cair emulsi.

Sistem transpor melalui membran cair organiik dapat digunaikan untuik memisahkan senyawa organik yang sulit dicapai dengan metode lain dan untuk pengayaan atau pengambilan ulang. Transpor fenol melalui membran cair memainkan peranan yang penting di dalam menirukan fungsi membran biologi dan teknologi pemisahan, karena metode ini mempunyai selektivitas dan efisiensi yang tinggi, mengurangi penggunaan jumlah pelarut dan pemisahan sejumlah ion dapat 
dilakukan secara kontinyu dalam satu unit operasi Ada beberapa jenis teknik LM yang telah dikembangkan yaitu membran cair ruah (bulk liquid membrane, BLM). membran cair berpendukung (supportedlfquid membrane, SLM) dan membran cair berisi (contained ligued membrame, CLM) (Nghiem et al., 2006). Metode SLM masih diragulcan tingkat kestabilannya terhadap kebocoran molckul carrier saat proses transpor. Beberapa peneliti telah menemukan bentuk modifikasi SLM yang dianggap mampu meningkatkan kestabilan SLM, yaitu dengan metode PIM (Polymer Incinsion Membrane). PIM terdiri dari polimer support, molekul carrier dan plastictzer.

Eugenol merupakan salah satu komponen kimia yang terdapat dalam miryak daun cengkch. Eugenol dalam daun cengkeh ini dapat digunakan sebagai bahan awal sintesis suatu senyawa karena mengandung tiga gugus fungsional yaitu gugus alil, eter, dan fenol (Amwar,1994), oleh karena itu eugenol dapat dipolimerisasi menjadi polieugenol. Membran PIM dibuat menggunakan larutan yang mengandung molekul carrier atau elstraltan, plasticizer dan polimer dasar seperti selulosatriasetat (CTA) atau polivinilklorida (PVC) membentuk lapisan yang tipis, stabil dan fleksibel. Hasilnya adalah membran self-supporting yang dapat digunakan untuk memisahkan larutan yang diinginkan dengan cara yang mirip dengan SLM (Nghiemet al., 2006).

Metode PIM memiliki kelebihan dibanding SLM dalam hal kestabilan dan dapat mengimbangi SLM dengan membuat membran yang tipis sehingga koefisien difusi menjadi rendah. Berbeda dengan SLM, kehilangan molekul carrier saat proses ekstraksi pada PIM dapat diabaikan (Tayebet al., 2005). Keunggulan dari metode PIM adalah mudah dalam sistem operasinya, dapat meminimalkan penggunaan bahan kimia, komposisi membran yang fleksibel dan selektif sebanding dengan pemisahan yang efisien (Nghiemet al., 2006).

Berdasarkan uraian tersebut, maka dalam penelitian ini akan disintesis polieugenol sebagai senyawa pembawa (carrier) kemudian dicetak bersama dengan DBE dan PVC sebagai membran PLM untuk transpor fenol menggunakan metode PIM. Evaluasi terhadap membran polieugenol dilakukan analisis kuat tarik membran (tensile strength) menggunakan Universal Testing Machine dan jumlah komponen yang hilang MI loss selama proses transpor. Terakhir, untuk mengetahui perbedaan fisik membran PIM. maka membran sebelum dan sesudah transpor dikarakterisasi menggunakan Scanning Electron Microscope (SEM) dan Fourier Transform infra Red (FITR).

\section{METODE PENEI.TIIAN}

Bahan

Bahan - bahan yang digunakan pada penelitian ini adalah bahan kimia kualitas pure analysis produksi Merck yaitu fenol, kloroform, dibenzileter (DBE), polivinilklorida (PVC), tetrahidrofuran (THF), $\mathrm{NaOH}, \mathrm{HCl}, 4$-aminoantipirin, $\mathrm{K} 4 \mathrm{Fe}(\mathrm{CN})_{4}, \mathrm{NH}_{4} \mathrm{OH}, \mathrm{K}_{2} \mathrm{HPO}_{4}, \mathrm{KH}_{4} \mathrm{PO}_{4}$, metanol, akuades (Laboratorium Kimia Analitik (GM) dan $\mathrm{pH}$ indikator.

\section{Alat}

Alat - alat yang digunakan pada penelitian ini adalah satu rangkaian alat transpor fenol berupa chamber dan pengaduk magnet, corong pisah, alat penunjang berupa alat - alat gelas dan plastik, $\mathrm{pH}$ meter (HM-30R), neraea analitik (Mettler ToledoAB54-S), spektrofotometer UV-Vis $\quad(772$ Spectrophotometer), spektrofotometer infra merah (Thermo Nicolet Avatar 360), H-NMR, Untversal Testing Machine (Zwick/Z0,5) dan Analytical Scanning Electron Mficroscope (HitachiSU8000) danSpektrometer infra merah (FIIR, Shimadzu Prestige-21).

\section{Prosedur}

\section{Sintesis Polieugenol}

Prosedur sintesis mengikuti prosedur yang telah dilakukan olch 
Kiswandono, dkk., (2012), Memasukkan $5,8 \mathrm{~g}$ eugenol ke dalam labu leher tiga kapasitas $125 \mathrm{~mL}$, kemudian ditambahkan $0,25 \mathrm{~mL} \mathrm{BF}_{3} \mathrm{O}\left(\mathrm{C}_{2} \mathrm{H}_{5}\right)_{2}$ sebagai katalis. Penambahan katalis ini dilaknkan setiap 1,5 jam sekali sampai 4 kali penambahan sambil diaduk dengan pengaduk magnet. Adanya reaksi ditandai dengan perubahan warna larutan menjadi merah Pada penambahan katalis terakhir, reaksi polimerisasi dilanjutkan hingga satu malam dan dihentikan dengan menambahkan $1 \mathrm{~mL}$ metanol. Gel yang terbentuk dilarutkan dalam eter kemudian dipindahkan dalam corong pisah kemudian dicuci berkali-kali dengan aquades hingga $\mathrm{pH}$ netral. Lapisan organik dipindahkan ke dalam labu erlenmeyer kapasitas $50 \mathrm{~mL}$ dan ditambah $\mathrm{Na}_{2} \mathrm{SO}_{4}$ anhidrat kemudian didekantasi. Pelarutnya diuapkan dengan labu penguap putar pada suhu $40^{\circ} \mathrm{C}$ dan residu disimpan dalam desikator. Padatan atau polimer yang terbentuk ditimbang dan polimer dikarakterisasi dengan FT- IR, SEM dan 'H NMR.

\section{Pencetakan membran}

Sebanyak $0,0270 \mathrm{~g}$ polieugenol, $0,0864 \mathrm{~g}$ PVC dan $0,1566 \mathrm{~g}$ DBE dilanutkan dengan $10 \mathrm{~mL}$ pelant tetrahidrofuran (THF) dan diaduk dalam cetakan membran. Setelah semua bahan tereampur secara homogen, membran didiamkan selama 48 jam hingga kering. Kekuatan membran diuji menggunakan tensile strenght dan karakterisasi membran dilakukan dengan analisis permukaan membran menggunakan Scanning Electron Mtcroscope (SEM) dan Foturier Transform Infra Red (FTIR).

\section{Transpor phenol}

Membran polieugenol dipasang pada chamber antara fasa sumber dan pelucut, sisi fasa pelueut diisi $50 \mathrm{~mL}$ $\mathrm{NaOH} 0,25 \mathrm{M}$ dan sisi fasa sumber diisi 50 $\mathrm{mL}$ larutan fenol $60 \mathrm{ppm}$ dengan $\mathrm{pH} 5,5$. Chamber ditutup lalu pada asing - masing fasa diaduk selama 48 jam pada suhu kamar. Setelah selesai diaduk, konsentrasi fenol yang terdapat pada fasa sumber dan fasa pelucut dianalisis menggunakan spektrofotometer UV-Vis pada panjang gelombang $460 \mathrm{~nm}$. Metode tes folometrik ini berbasis pada reaksi wama dari stem distillable penolik dengan 4-aminoantipirin pada $\mathrm{pH} \quad 10 \neq 0,2$ pada lingkungan $\mathrm{KJF}(\mathrm{CN})_{\text {c. }}$ Warna antipirin yang terbentuk diekstraksi menggunakan kloroform lalu absorbansinya diukur pada panjang gelombang $460 \mathrm{~nm}$.

\section{Evaluasi Membran Polieugenol}

Membran polieugenol sebelum dan sesudah transpor di timbang setelah dikeringkan selama 48 jam untuk mengetahui komponen penyusun membran yang hilang (ML lass). Perbedaan fisik membran polieugenol (kekuatan dan morfologi permukaan membran) diketahui dengan cara analisis menggunakan Universal Testing Machine (Zwick/Z0,5) kemudian dikarakterisasi menggunakan Scanning Electron Microscope (SEM) dan Fourier Transform Infra Red (FIIR).

\section{HASIL DAN PEMBAHASAN}

\section{Sintesis Polieugenol}

Dari sintesis yang telah dilakukan diperoleh padatan polieugenol yang secara fisik berwujud padat dengan berat $4,7005 \mathrm{~g}$ (rendemen $80,74 \%$ ). Dalam hal ini, eugenol mempunyai 3 gugus fungsional yaitu alil, hidroksi, dan metoksi. Melalui gugus alil, eugenol dipolimerisasi menjadi polieugenol. Reaksi polimerisasi cugenol menjadi polieugenol merupakan suatu proses polimerisasi kationik. Monomer eugenol yang mengandung ikatan rangkap $\mathrm{C}=\mathrm{C}$ dapat mengalami polimerisasi radikal. Reaksi polimerisasi eugenol membutuhkan katalis yaitu $\mathrm{BF}_{3} \mathrm{O}\left(\mathrm{C}_{2} \mathrm{H}_{3}\right)_{2}$. Senyawa $\mathrm{BF}_{3}$ merupakan asam lewis kuat, yaitu senyawa pencrima pasangan elektron, sedangkan $\mathrm{C}_{2} \mathrm{H}_{3}-\mathrm{O}_{-}-\mathrm{C}_{2} \mathrm{H}_{3}$ adalah basa lewis, yaitu senyawa pemberi pasangan elektron. Adanya gugus-gugus pelepas elektron pada cugenol dan katalis yang digunakan menycbabkan terjadinya polimerisasi kationik schingga akan menghasilkan polieugenol. 


\section{Karakterisasi Polieugenol}

Untuk mengetahui telah terbentuknya polieugenol, diperlukan karakterisasi. Pada penelitian ini telah dilakukan karakterisasi sampel dengan FTIR Adapun spektra inframerah dari cugenol dan polieugenol dapat dilihat pada Gambar 1. Spektra eugenol (Gambar la) memiliki gugus-gugus karakteristik yakni senyawa aromatis yang ditunjukkan oleh pita serapan $\mathrm{C}-\mathrm{H}$ tekukan (bending) ke luar bidang $817,82 \mathrm{~cm}^{-1}$ (biasanya pada rentang pita $900-800 \mathrm{~cm}^{-1}$ ) yaitu suatu senyawa aromatis tersubtitusi $1,2,4$. Gugus tak jenuh vinil $\left(-\mathrm{C}=\mathrm{CH}_{2}\right)$ pada 995,27 dan $910,40 \mathrm{~cm}^{-1}$, regangan (stretching) C-H dari gugus alkil metil $\left(-\mathrm{CH}_{3}\right)$ pada 1365,60 $\mathrm{cm}^{-2}$, gugus metilen $\left(-\mathrm{CH}_{2}\right)$ pada 1435,04 $\mathrm{cm}^{-1}$, gugus alil merupakan rentangan $\mathrm{C}=$ $\mathrm{Csp}^{2}$ pada $1636,5 \mathrm{~cm}^{-1}$ yang diperkuat dengan $C=C \mathrm{sp}^{2}$ keluar bidang pada $900-$ $650 \mathrm{~cm}^{-1}$ dan uhuran $-\mathrm{OH}$ pada serapan $3448,72 \mathrm{~cm}^{-1}$.

Jika dibandingkan dengan spektra polieugenol (Gambar 1b) terlihat bahwa, scrapan gugus alil $\left(1636,5 \mathrm{~cm}^{-1}\right)$ dan serapan gugus vinil $\left(995,27 \mathrm{~cm}^{-1}\right)$ tidak terlihat lagi, selain itu didukung pula dengan hilangnya serapan - serapan pada dacrah $1000-650 \mathrm{~cm}^{-1}$. Hal ini menunjukkan telah terjadi reaksi adisi terhadap ikatan rangkap pada eugenol, artinya telah terjadi reaksi polimerisasi eugenol dan terbentuk polieugenol. Analisis spektra IR secara lengkap dapat dilihat pada Tabel 1.

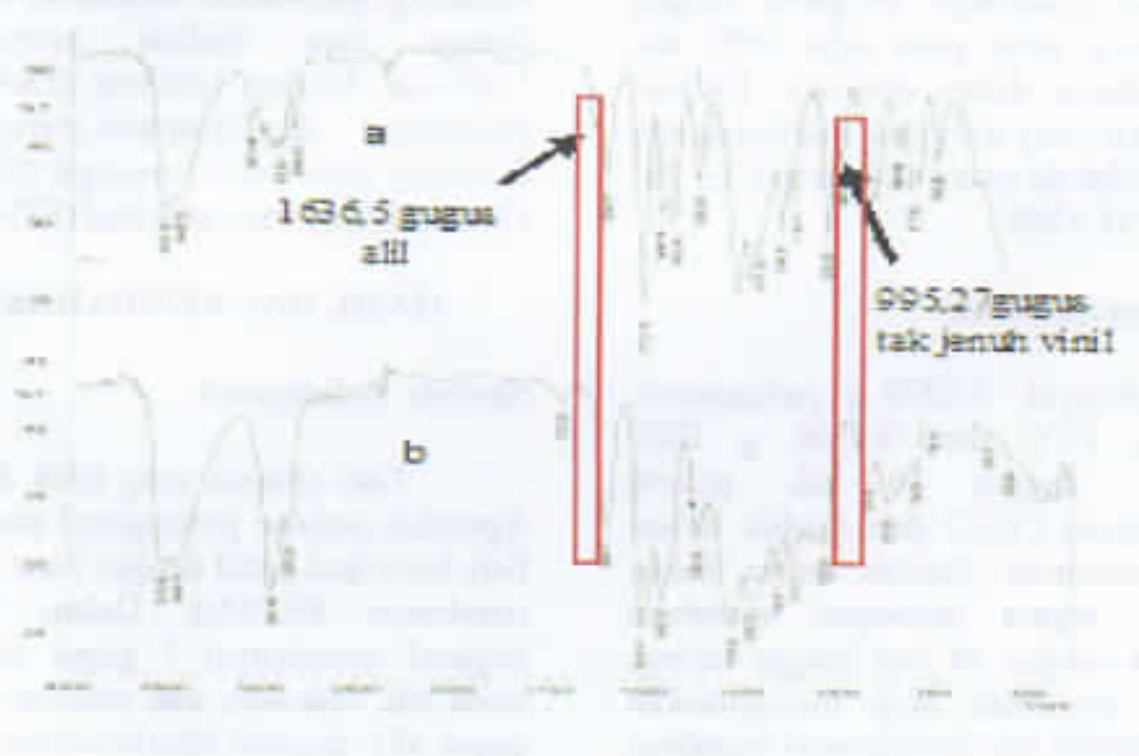

Gambar 1. Spektra IR dari eugenol (a) dan polieugenol (b)

Tabel 1. Analisis spektra IR eugenol dan polieugenol

\begin{tabular}{lll}
\hline Serapan pada cugenol $\left(\mathrm{cm}^{-1}\right)$ & Serapan pada polieugenol $\left(\mathrm{cm}^{-1}\right)$ & Gugus karakteristik \\
\hline 1033,85 & 1033,85 & $\mathrm{C}-\mathrm{O}-\mathrm{C}$ \\
1636,5 & tidak ada & $\mathrm{C}=\mathrm{C}$, vibrasi ulur \\
995,27 & tidak ada & $-\mathrm{CH}=\mathrm{CH}_{2}$ \\
$3000-2800$ & $3000-2800$ & $\mathrm{Gugus}$ alkil \\
1365,60 & 1365,60 & $-\mathrm{CH}$ \\
1458,18 & 1458,18 & $-\mathrm{C}=\mathrm{C}$-aromatis \\
512,19 & 1512,19 & $-\mathrm{C}=\mathrm{C}$-aromatis \\
1604,77 & 1604,77 & $-\mathrm{C}=\mathrm{C}$-aromatis \\
\hline
\end{tabular}


Guna mendukung data terbentuknya polieugenol dari eugenol dilakukan analisis sampel dengan ${ }^{1} \mathrm{H}$ NMR. Spektra 'H-NMR terlihat pada Gambar 2. Gambar 2 memberikan informasi bahwa terjadi serapan pada beberapa daerah, yaitu pergeseran kimia pada $6,3-7,0$ yaitu proton $3 \mathrm{H}$ dari benzena, pergeseran kimia pada 2,5-3,3 adalah proton $2 \mathrm{H}$ dari $-\mathrm{CH}_{2}$, serta munculnya puncak multiplet pada pergeseran $0,6-1,4$ yang merupakan karakteristik dari gugus metil $-\mathrm{CH}_{3}$, ini merupakan tulang punggung polimer.
Scbagai pembanding disajikan spektra 'H-NMR eugenol yang tersaji dalam Gambar 3. Spektra IH-NMR eugenol ini merupakan hasil penelitian Kartikawati (2007). Gambar 2 menunjukkan adanya pergeseran kimia untuk $2 \mathrm{H}$ dari $-\mathrm{CH}=\mathrm{CH}_{2}$, pada $5,0-5,3$ $\mathrm{ppm}$, tetapi pergeseran kimia ini tidak ditemui pada Gambar 2 sehingga dengan demikian disimpulkan telah terjadi reaksi polimerisasi eugenol menjadi polieugenol (Setyowati, 1998).

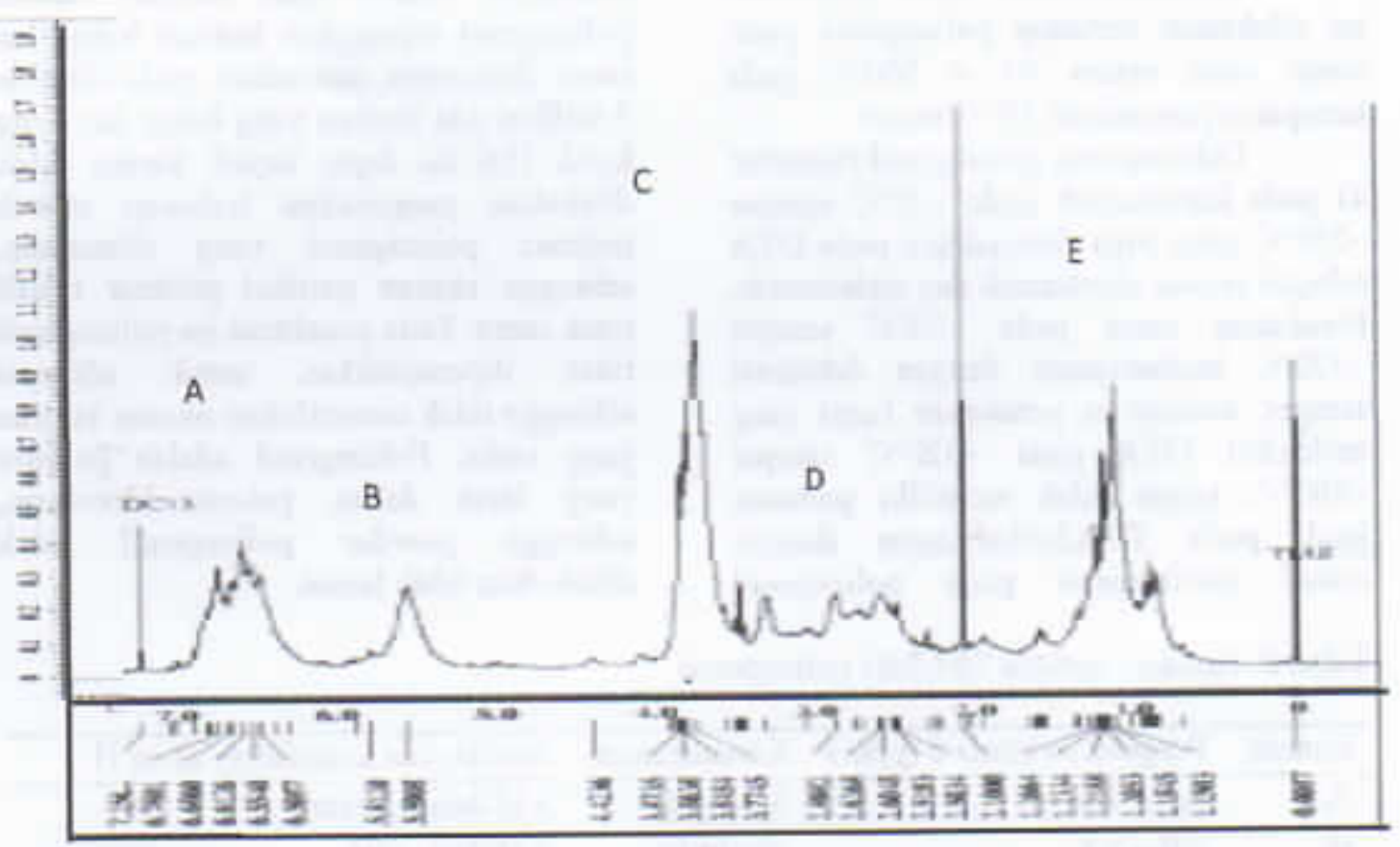

Gambar 2. Spektra 'H-NMR polieugenol

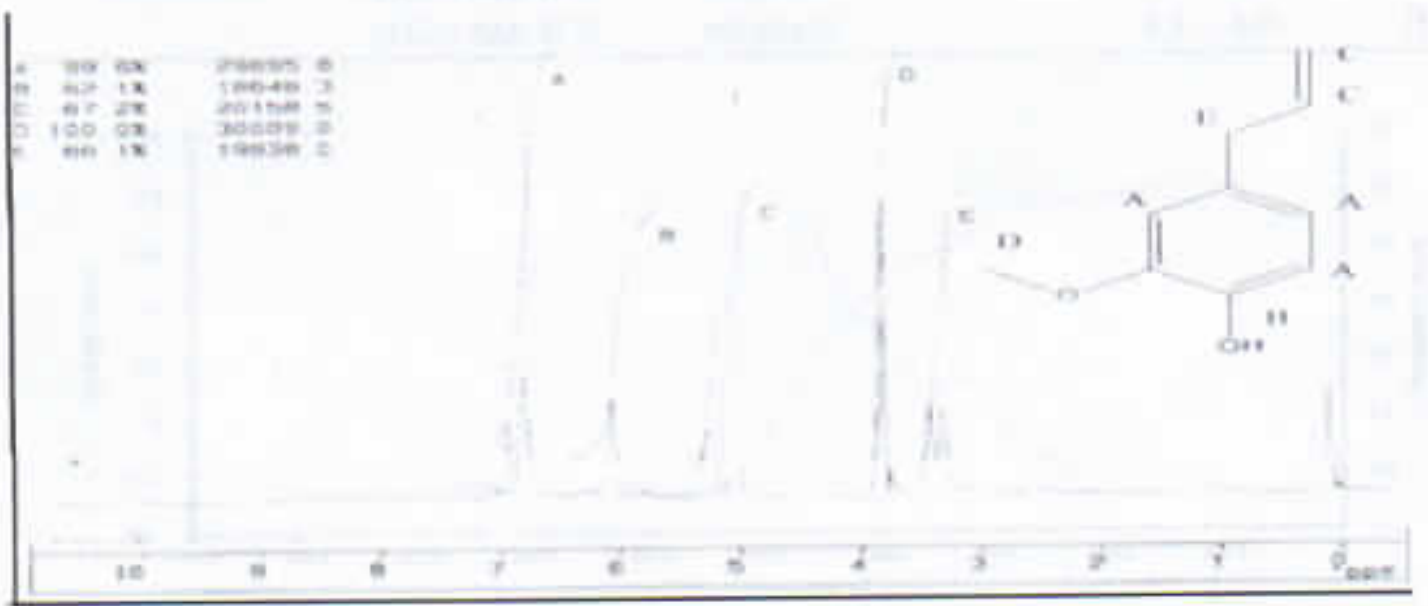

Gambar 3. Spcktra 'H-NMR eugenol (Kartikawati, 2007) 
Sementara, analisis 'H-NMR selengkapnya dapat dilihat pada Tabel 2 . Untuk lebih mempertegas terbentuknya polimer, yakni polieugenol maka dilakukan analisis menggunakan Thermogravimetric Analysis (TGA). Termogravimetri adalah teknik untuk mengukur perubahan berat dari suatu senyawa sebagai fungsi dari temperatur. Hasilnya berupa rekaman diagram yang kontimu dan menunjukkan reaksi dekomposisi bertahap yang skematik. Pengurangan massa (dekomposisi) polimer disebabkan adanya proses termokimia.

Termogravimetri pada penelitian ini dilakukan terhadap polieugenol pada range suhu antara $30-900^{\circ} \mathrm{C}$ pada kecepatan pemanasan $10^{\circ} \mathrm{C}$ menit.

Dekomposisi polieugenol (Gambar 4) pada kurvaterjadi pada $-33^{\circ} \mathrm{C}$ sampai $-550^{\circ} \mathrm{C}$ yang juga ditunjukkan pada DTA sebagai proses eksotermik dan endotermik. Perubahan berat pada $-33^{\circ} \mathrm{C}$ sampai $-320^{\circ} \mathrm{C}$ bethubungan dengan dehidrasi sampel, sedangkan perubahan berat yang terdetcksi DTA pada $-320^{\circ} \mathrm{C}$ sampai $-395^{\circ} \mathrm{C}$, tetapi tidak memiliki padanan jejak pada TGA,berhubungan dengan reaksi rekristalisasi pada polieugenol terdehidrasi. Proses ke dua ini bersifat endotermik, kemudian diikuti dengan eksotermik pada interpaltemperatur $-395^{\circ} \mathrm{C}$ sampai $-545^{\circ} \mathrm{C}$ menunjukkan bahwa struktur yang diadopsi antara $\sim 395^{\circ} \mathrm{C}$ sampai $\sim 545^{\circ} \mathrm{C}$ bersifat metastabil. Proses eksotermik DTA ini menandakan penurunan entalpi sampel dan mengindikasikan perubahan ke struktur yang lebih stabil.

Karakterisasi lain yang telah dilakukan pada penelitian ini yaitu analisis sampel menggunakan SEM. Hasil analisis SEM dapat tertihat pada Gambar 5. Pada umumnya secara fisik terlihat serbuk polieugenol merupakan butiran halus dan sama ukurannya, sementara pada Gambar 5 terlihat ada butiran yang besar dan yang kecil. Hal ini dapat terjadi karena tidak dilakukan pengayakan terhadap serbuk polimer polieugenol yang dihasilkan, schingga ukuran partikel polimer relatif tidak sama. Pada penelitian ini polieugenol tidak diperuntukkan untuk adsorpsi schingga tidak memerlukan ukuran butiran yang sama. Polieugenol adalah polimer yang larut dalam pelarut kloroform. sehingga powder polieugenol tidak dihaluskan lebih lanjut.

Tabel 2. Analisis spektra 'H-NMR polieugenol

\begin{tabular}{llll}
\hline Puncak & Pergeseran kimia $\delta(\mathrm{ppm})$ & Kenampakan & Jumlah dan kedudukan atom $\mathrm{H}$ \\
\hline A & $6,3-7,0$ & Multiplet & $3 \mathrm{H}$ dari benzena \\
B & $5,0-5,5$ & Multiplet & $1 \mathrm{H}$ dari-OH \\
C & $3,5-4,0$ & Singlet & $3 \mathrm{H}$ dari $-\mathrm{OCH}_{3}$ \\
D & $2,5-3,3$ & Multiplet & $2 \mathrm{H}$ dari- $\mathrm{CH}_{2}$ \\
E & $0,6-1,4$ & Multiplet & $3 \mathrm{H}$ dari $-\mathrm{CH}_{6}$ \\
\hline
\end{tabular}

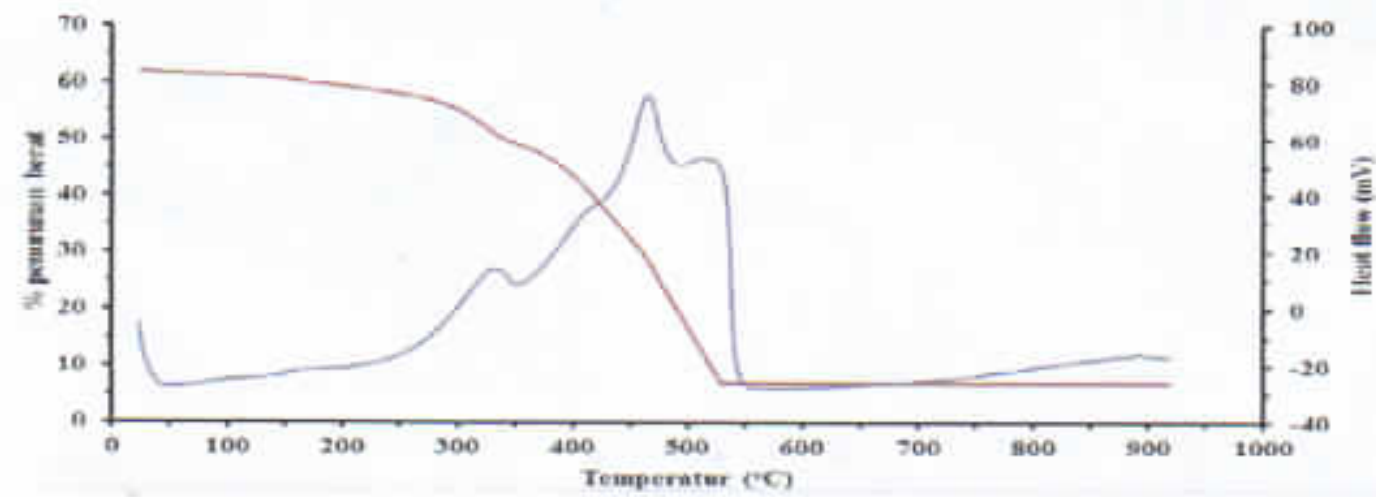

Gambar 4. Termogram TG/DTA polieugenol 


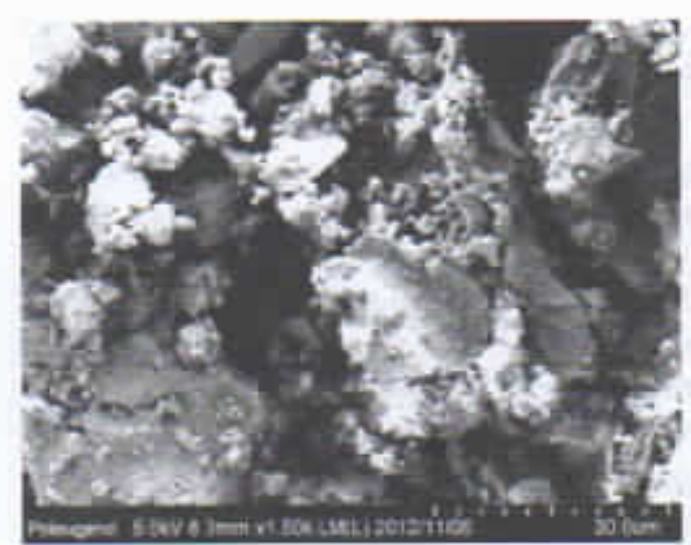

Gambar 5. Hasil SEM polieugenol $150 \mathrm{x}$

Pembuatan Membran PIM dan Uji Transpor fenol

PIM dibuat dengan komposisi polieugenol, polivinillklorida (PVC), dan dibenzileter (DBE). Polieugenol berfungsi sebagai membran carrier yang membawa fenol dalam sistem secara altif. Polivinilklorida (PVC) berfungsi sebagai polimer pendukung yang mengimmobilisasi carrier polieugenol dan dibenzileter (DBE) berfungsi sebagai plasticizer yang membuat PIM menjadi lebih clastis dan tidak rapuh. Transpor fenol melalui membran terjadi melalui mekanisme transpor akibat gradien konsentrasi fenol pada fasa sumber dan fasa pelucut. Transpor balik fenol ke fasa membran dicegah dengan menambahkan stripping agent, $\mathrm{NaOH} \mathrm{ke}$ dalam fasa pelucutStripping agent bekerja mengkonversi fenol menjadi senyawa turunannya, yaitu natrium fenolat dan menjebak senyawa tersebut dalam fasa pelucut sehingga tidak kembali ke fasa membran (Mortaheb et al. 2008). Untuk mengetahui pengaruh waktu transpor dalam proses transpor fenol, dilakukan transpor dengan pemakaian satu, dua dan tiga kali. Chamber (Gambar 6) yang telah berisi fasa sumber yaitu $50 \mathrm{~mL}$ larutan fenol dengan konsentrasi $60 \mathrm{ppm}$ dan fasa pelucut yaitu $50 \mathrm{~mL}$ larutan $\mathrm{NaOH}$ dengan konsentrasi $0,25 \mathrm{M}$, selanjutnya diaduk pada suhu kamar menggunakan stirrerselama 48 jam. Setelah pengadukan selesai, dilakukan pemisahan antara fasasumber dan fasa pelucut.

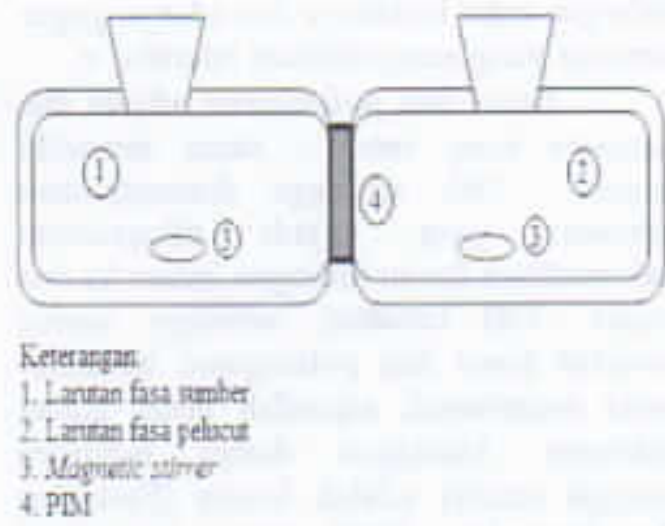

Gambar 6. Skema alat transpor fenol dengan metode PIM

Untuk memastikan membran polieugenol dapat mentranspor fenol, dilakukan pengulangan hingga lima kali. Hasil perhitungan tersaji pada Gambar 7. Dapat diketahui dari Gambar 7 bahwa polieugenol sebagai senyawa pembawa mampu mentranspor fenol antara $41 \%$ sampai $49 \%$. Bahkan pada pengulangan kelima, terlihat bahwa, konsentrasi fenol pada fasa sumber tinggal $16 \%$, ini artinya bahwa $84 \%$ fenol pada fasa sumbersudah memasuki fasa membran tetapi belum mencapai fasa pelucut. Fenol yang mencapai fasa pelucut hanya $41 \%$ saja, artinya bahwa sisi aktif pada polieugenol belum mampu untuk dapat mentranspor fenol secara keseluruhan, sehingga fenol hanya tertahan pada fasa membran. Demikian juga yang terjadi pada pengulangan ketiga, teriihat bahwa fenol pada fasa pencrima tinggal $26 \%$, artinya bahwa fenol yang sudah tertranspor mencapai $74 \%$ Gambar 7 juga memperlihatkan bahwa terdapat selisih antara konsentrasi fenol pada fasa pelucut dan fasa sumber, selisih tersebut (rata rata $23 \%$ ) terdapat atau tertahan pada fasa membran. Hal ini mengindikasikan bahwa polieugenol sebagai senyawa pembawa hanya mampu mentranspor fenol rata-rata $46 \%$ Kemampuan polieugenol tidak terlepas dari sisi aktif yang dimilikinya, artinya bahwa sisi aktif polieugenol belum mampu untuk mentranspor fenol secara maksimal. Interaksi antara fenol- dan policugenol telah dipredilcsi sebagai interaksi yang terjadi karena adanya ikatan 
hidrogen antar keduanya dan adanya gugus benzena yang menyebabkan interaksi $\pi$.

Fenol dan polieugenol adalah dua senyawa yang sama - sama memiliki gugus $-\mathrm{OH}$, sehingga dimungkinkan interaksi yang terjadi dikarenakan terbentuknya ikatan hidrogen antara ke dua gugus $\mathrm{OH}$ tersebut, sehingga semua molekul fenol dan polieugenol bersamasama membentuk scjumlah besar ikatan hidrogen. Meskipun ikatan hidrogen tunggal sendiri adalah lemah (Fesenden dan Fesenden, 1990), tetapi kombinasi elektron dari kedua molekul menyebabkan terjadinya ikatan hidrogen yang cukup kuat, sehingga dalam spektra inframerah dapat memberikan kekhasan pada fenolpolicugenol dibandingankan inframerah fenol maupun polieugenolnya sendiri. Polieugenol dan fenol juga sama-sama mempunyai cincin benzena, sehingga dimungkinkan keduanya membentuk interaksi dengan interaksi $\pi$. Suatu polimer yang mempunyai kemampuan untuk membentuk interaksi $\pi$ dengan senyawa lain akan membentuk suatu interaksi yang lebih stabil. Polieugenol dapat membentuk interaksi $\pi$ karena mempunyai dua atau lebih cincin benzena,sehingga dimungkinkan fenol dan polieugenol juga dapat berinteraksi karena adanya ikatan $\pi$ (Kiswandono,

2010).

\section{Evaluasi transpor fenol}

Selama proses transpor fenol dari fasa sumber ke fasa pelucut yang melewati membran polieugenol memungkinkan akan hilangnya beberapa komponen penyusun membran (leaching) sehingga akan mengurangi kemampuan transpor jika membran tersebut digunakan kembali. Besar atau kecil komponen penyusun membran yang hilang akan tergantung pada beberapa faktor, diantaranya adalah kecepatan stirer, jumlah plastisicer yang digunakan dan waktu transpor (Kiswandono, 2013).

Komponen membran yang hilang (ML. lass)pada penelitian ini berkisar antara $11 \%$ sampai $21 \%$ yang hilang saat proses transpor ditunjukkan pada Gambar 8 menunjukkan bahwa saat pengulangan yang ketiga, teradi ML loss yang tinggi hingga mencapai $21 \%$.

Hal ini dikarenakan bahwa, fenol yang sudah mencapai fasa membran sudah mencapai $74 \%$ walaupun akhimya fenol yang mencapai fasa pelucut hanya $41 \%$. Berbeda denan pengulangan yang kelima, dimana fenol yang sudah mencapai fasa membran $84 \%$ tetapi MI lossnya hanya $16 \%$. Faktor yang berperan pada saat pengulangan kedua dan ketiga kemungkinan adalah faktor stirrer. Penggunaan stirrer dengan kecepatan yang tinggi dapat mengakibatkan gangguan pada permukaan membran yang berupa gesekan antara larutan dan permukaan membran schingga mengakibatkan ML loss yang tinggi. Gambar tersebut juga menunjukkan bahwa membrane loss pada polieugenol termasuk tinggi, yakni mencapai (ratarata) $17 \%$ sehingga diperlukan suatu modifikasi, baik senyawa pembawanya maupun desain alatnya sehingga dihasilkan ML loss yang rendah.

Pada penelitian ini dihasilkan lembaran PIM dengan diameter efektif 2,5 $\mathrm{cm}$. Hasil karakterisasi permukaan PIM dengan menggunakan scanning electron microscope ditunjukkan pada Gambar 9, yakni permukaan membran sebelum dan sesudah transpor. Hasil SEM menunjukkan bahwa, membran PM memiliki rogga pori, ini terlihat pada membran setelah transpor. Scbelum transpor, polimer polieugenol menutup pori membran, sehingga terlihat permukaan membran rata. Adanya pori membran ini membantu proses transpor senyawa fenol, sehingga transpor fenol dapat dilakukan.

Permukaan membran setelah digunakan untuk transpor fenol terlihat memiliki rongga. Rongga - rongga ini terbentuk karena adanya spesies membran yang hilang. Selama proses, membran digunakan untuk transpor fenol dari fasa sumber ke fasa pelucut, kemungkinan terdapat spesies membran yang ikut terbawa menuju ke fasa pelucut.

Kuat tarik membran sebelum dan setelah transpor selanjutnya diuji menggunakan alat Universal Testing Machine (UTM). Uji tarik dilakukan untuk memberikan informasi kekuatan suatu 
bahan. Pada uji tarik, benda uji diberi beban gaya tarik secara vertikal yang bertambah secara kontinu, bersamaan dengan itu dilakukan pengamatan terhadap perpanjangan yang dialami benda uji.

Hasil lauat tarik menunjukkan bahwa kuat tarik membran setelah transpor lebih kecil daripada sebelum transpor. Kuat tarik membran setelah transpor fenol adalah $6,85 \mathrm{MPa}$ lebih kecil daripada kuat tarik membran sebelum transpor fenol yang besamya 7,82 MPa. Selama proses, membran digunakan untuk transpor fenol dari fasa sumber $k e$ fasa pelueut, kemungkinan terdapat spesies membran yang ikut leaching menuju fasa pelucut.

Salah satu kemungkinan leaching berasal dari DBE sebagai spesies yang membuat membran menjadi elastis dan tidak rapuh. Berkurangnya jumlah DBE pada membran setelah proses transpor fenol menyebabkan kekuatan membran berkurang dan kuat tarik menjadi lemah. Nghiem et al. (2006) mengatakan bahwa beberapa studi FTIR menyatakan tidak ada tanda pembentukan ikatan kovalen antara carrier, plasticizer dan skeleton membrane dasar, sepertinya antar mereka terikat satu dengan lainnya dengan membentuk ikatan secondary seperti ikatan hidrofobik, wam der Waals atau hidrogen. Hal ini dibuktikan dengan spektra FIIR yang ditunjukkan pada Gambar 11. interaksi suatu senyawa dengan senyawa lainnya secara kualitatif dapat diketahui dengan spektra inframerah, karena spektra inframerah merupakan kekhasan sebuah molekul secara menyeluruh. Gugus gugus atom tertentu memberikan penambahan serapan pada kerapatan tertentu (Silversteinet et al., 1984). Interaksi fenol dengan membran carrier di dalam PIM dapat dilihat dengan karakterisasi FTIR yang ditunjukkan dengan spektra pada Gambar 10.

Serapan absorbansi OH pada puncak $3448,72 \mathrm{~cm}^{-1}$ yang semakin tajam menunjukkan penambahan gugus $-\mathrm{OH}$ oleh fenol dan absorbansi pada bilangan gelombang 740,67 $\mathrm{cm}^{-1}$ menunjukkan adanya gugus $\mathrm{C}-\mathrm{H}$ aromatis monosubstituen milik fenol. Gugus fungsi pada membran sebelum dan setelah proses transpor fenol dikarakterisasi menggunakan FTIR. Hasil karakterisasi ditunjukkan pada Gambar 10.

Adapun identifikasi gugus fungsi pada membran sebelum digunakan untuk transpor fenol menunjukkan beberapa puncak seperti pada Tabel 3.

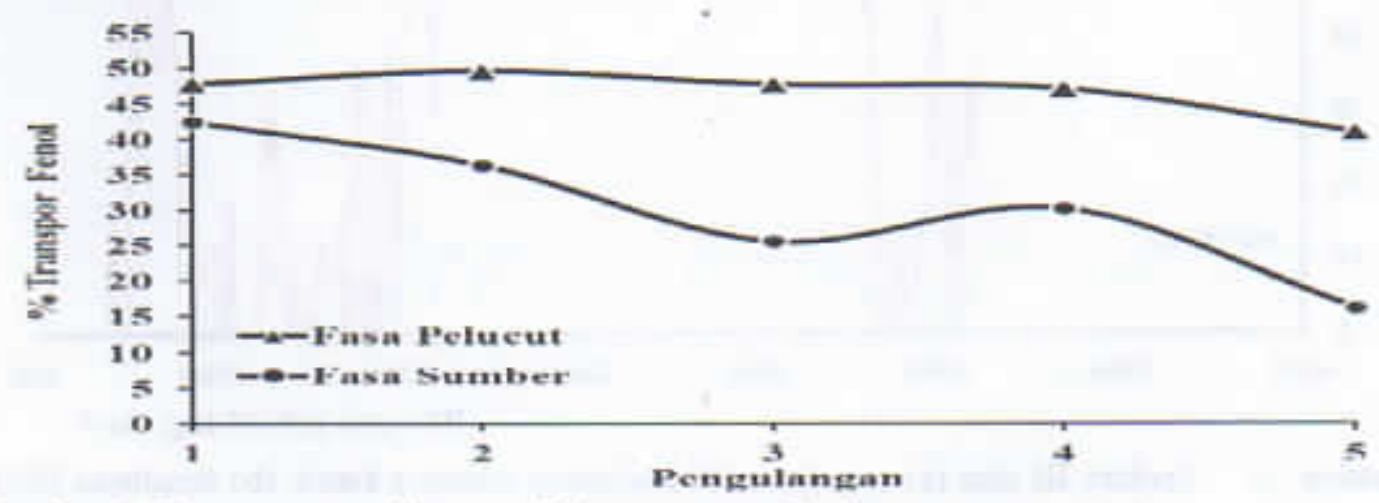

Gambar 7. Kemampuan polieugenol dalam transpor fenol

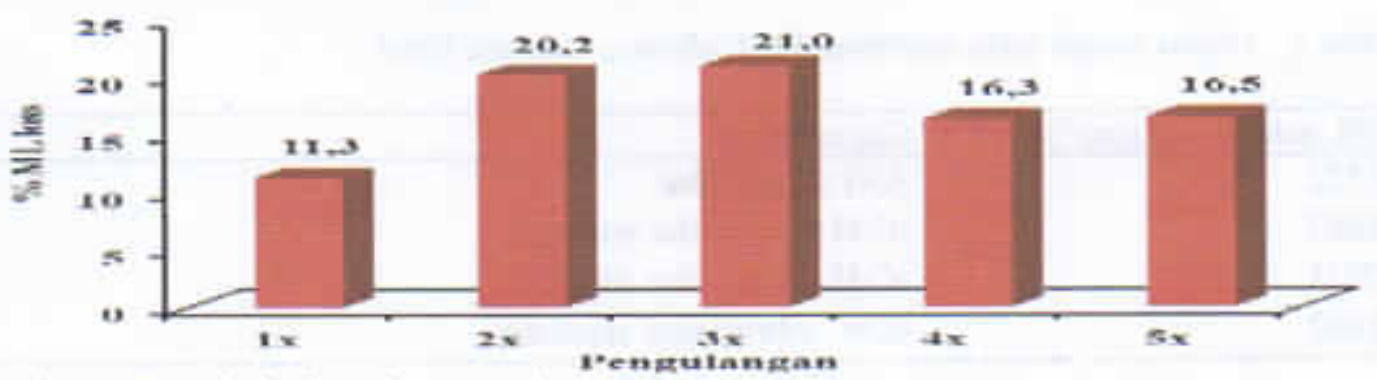

Gambar 8. Pemakaian berulang membran PIM 


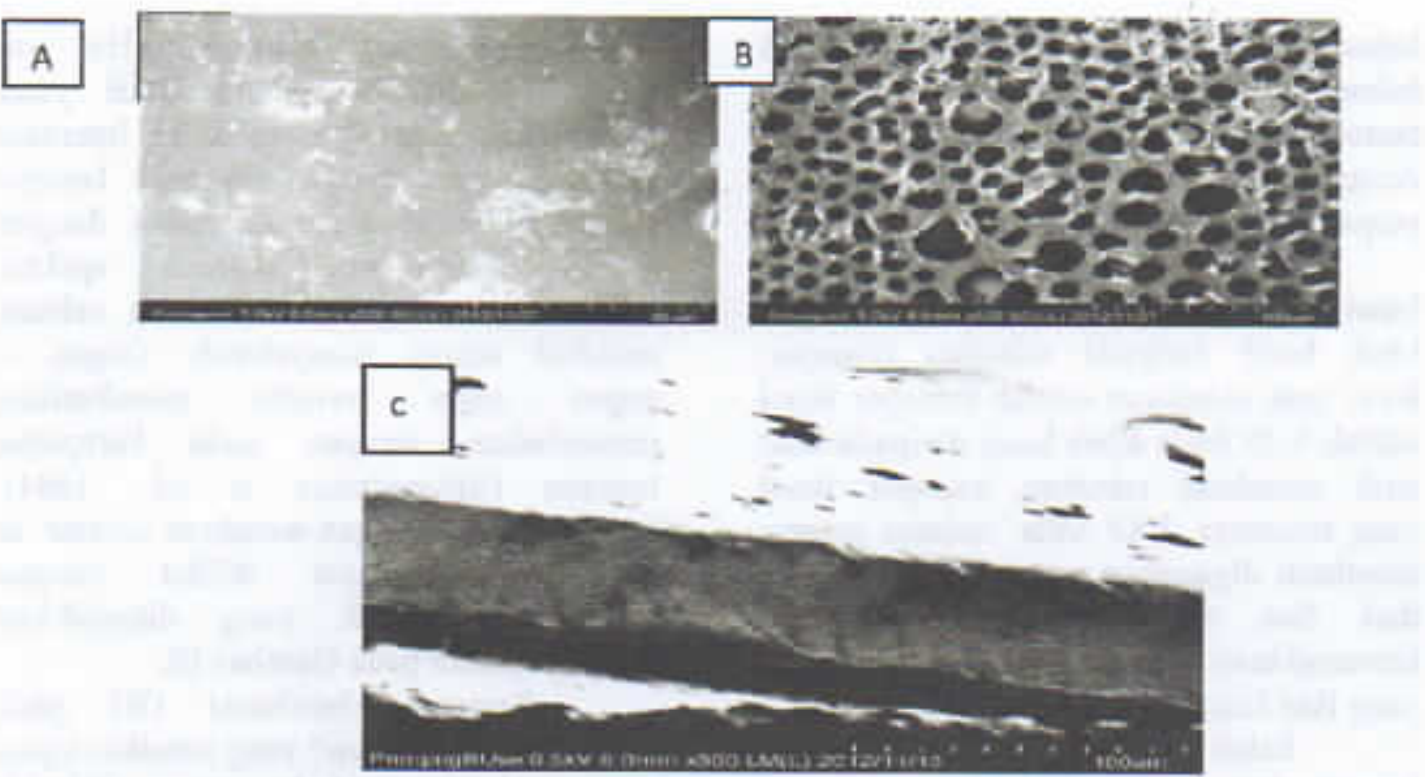

Gambar 9. Hasil karakterisasi membran PIM 500x (A) sebelum transpor, (B) setelah transpor dan (C) penampang membran

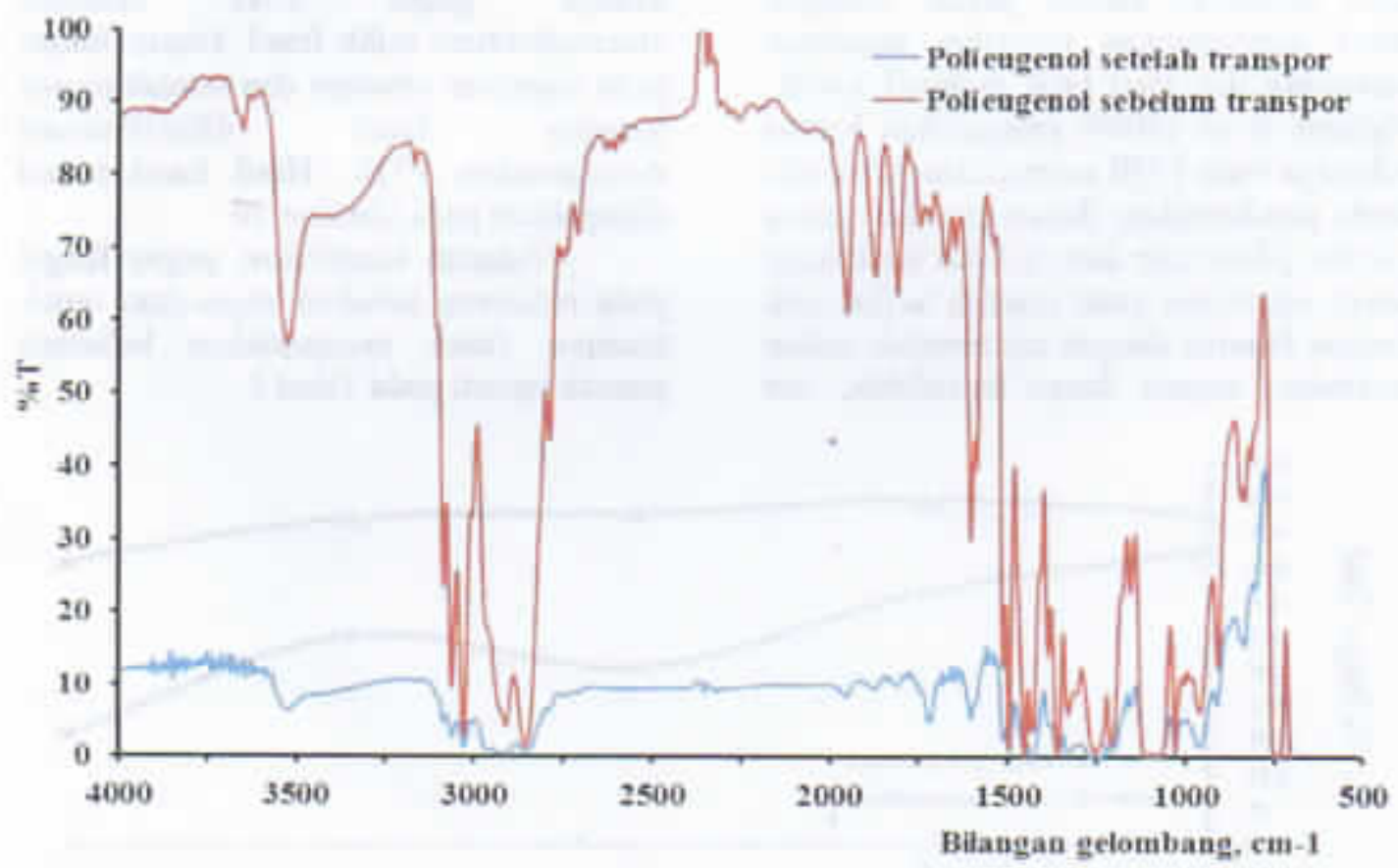

Gambar 10. Spektra IR dari (a) membran PIM sebelum transpor fenol, (b) membran PIM setelah transpor fenol

Tabel 3. Gugus fungsi pada membran PIM sebelum transpor fenol

\begin{tabular}{ll}
\hline Bil. gelombang $\left(\mathrm{cm}^{-1}\right)$ & Gugus fungsi \\
\hline 3522 & $-\mathrm{OH}$ vibrasi ulur \\
3062 & $-\mathrm{C}-\mathrm{H}$ vibrasi ulur aromatik \\
2911 & $-\mathrm{C}-\mathrm{H}$ vibrasi ulur alkana \\
1602 & $-\mathrm{C}-\mathrm{C}$ vibrasi ulur aromatik \\
\hline
\end{tabular}


Sebelum membran digunakan untuk transpor fenol, terdapat puncak dalam spektra $\mathbb{R}$ yang mengindikasikan adanya $-\mathrm{OH}$ stretching, $-\mathrm{CH}$ aromatik stretching, $-\mathrm{C}-\mathrm{H}$ alkana stretching $\mathrm{dan}-\mathrm{C}=$ C aromatik stretching. Serapan yang muncul merupakan scrapan milik kopoli (eugenol-DVB) scbagai molekul carrier peryusun membran. Setelah membran dipakai untuk transpor fenol, intensitas pada bilangan gelombang ini masih terlihat tetapi dengan intensitas yang rendah karena telah didominasi olch air. Hasil perbandingan dari kedua spektra menunjukkan bahwa gugus fungsi pada daerah bilangan gelombang $400-1500 \mathrm{~cm}^{-1}$ relatif tidak mengalami pergeseran maupun perbedaan intensitas. Pada bilangan gelombang $3522 \mathrm{~cm}^{-1}$ yang merupakan bilangan gelombang - $\mathrm{OH}$ stretching terlihat mengalami pelebaran puncak. $\mathrm{Hal}$ ini karena selama proses transpor, membran berada diantara dua fasa dan digunakan untuk melewatkan fenol dari fasa sumber ke fasa pelucut schingga ada air yang masuk kedalam pori-pori membran. Mernbran PIM merupakan membran yang tidak dapat kering seeara maksimal sehingga saat karakterisasi dengan FTIR, membran PIM masih mengandung air.

\section{KESIMPULAN}

Dari penelitian ini diperoleh hasil sintesis berupa serbuk polieugenol berwarna kuning kecoklatan dengan berat $4,7005 \mathrm{~g}$ (rendemen $80,74 \%$ ). Berdasarkan hasil karakterisasi polieugenol dengan $\mathrm{H}$ NMR, FT-IR, TG-DTA dan SEM, diperoleh informasi bahwa telah terjadi reaksi polimerisasi eugenol membentuk polieugenol. Uji transpor fenol dengan membran polieugenol menunjukkan bahwa membran PIM mampu mentranspor fenol dengan jumlah rata-rata $46 \%$. Hasil karakterisasi terhadap membran PIM dengan SEM, Universal Testing Machine dan FTIR, menunjukkan terjadinya perubahan morfologi membran PIM setelah digunakan untuk mentranspor fenol karena adanya spesies membran yang hilang selama proses transpor.

\section{UCAPAN TERIMA KASIH}

Terima kasih penulis ucapkan kepada program penelitian dosen muda dari DIKTI yang telah membiayai penelitian ini.

\section{DAFTAR PUSTAKA}

\section{Alva, V. A dan Peyton, B.M, 2003, Phenol and Catechol Btodegradation by the Haloalkaliphile Halomonas campisalis : Influenec of $\mathrm{pH}$ and Salinity.}

Anwar, C, 1994, The Conversion of Eugenol into More Vahuable Substances, Disertasi, F. MIPA, Universitas Gadjah Mada, Yogyakarta.

Cichy, W., and Szymanowski, J., 2002. Recovery of Phenol from Aqueous Streams in Hollow Fiber Modules, Environ. Sei. Technol, 36(9), $2088-2093$.

Drapala A, Dzygiel P, Jonson JA, Wieczorek P. 2001. Supported liquid membraneextraction of peptides. J Act Biochi Pol 48: $1113-1116$.

Fessenden dan Fessenden, 1990, Kimia Organtk jillid $I$ edisi 3 , Alih bahasa A. H. Pudjaatmaka, Penerbit Eriangga, Jakarta.

Kartikawati, N. G., 2007, Pemisahan Logam Berat Dengan Poliengenol Sebagai Carrier Menggunakan Teknik BLM (Bulk Liquid Mombrane), Skripsi. Jurusan Kimia FMIPA UNDIP.

Kusumastuti, A, 2007, Pemuithan fenol dari air limbah dengan membran cair emulst, Tesis Magister Teknik Kimia, Master lhesesfrom JBPTTTBPP.

http:/tf.lib itb.ac.id/gdl.phn?mod= browseहैop=read\&id=jbptitbpp- 
gdladhikusuma-25021], download, selasa, 20 jan 2009 jam 15.25.

Kiswandono, A. A, 2010, Studi Transpor Fenol dengan Mengginakan Membran Cair poliengenol, Tesis, Universitas Gadjah Mada, Yogyakarta.

Kiswandono, A. A., Siswanta, D., Aprilita, N. H. Santosa, S. J., 2012 Transport of phenol through inclusion polymer membrane (pim) using copoly(eugenol-aivb) as membrane carriarsInảo. J. Chem., $12(2), 105-112$.

Kiswandono, A. A., Siswanta, D., Aprilita, N. H., Santosa, S. J., 2013, Extending the Life Time of Polymer Inchuston Membrane Containing Copoly (Eugenol-DVB) as Carrier for Phenol Transport, Indo. J. Chem., 12(2), 105-112.

Garea, A, Urtiaga, A. M., Ortiz, M. I., Alonso, A. I, and Irabien, J. A. 1983, Phenol Recovery with SLM Using Cyanex 923, Chem. Eng. Comm., 120, 85-97.

Moraitopoulos, I. Ioannou, $Z$., and Simitzis, J., 2009, Adsorption of Phenol, 3.Nitrophenol and Dyes from Agueous Solutions Onto an Activated Carban Column Under Semi-batch and Continuous Operation, World Academy of Sctence, Eng.Techno., 58, 218221.

Mortaheb, HR., Amini, MH., Sadeghian, F, Mokhtarani, B., Daneshyar, H, 2008, Study an a new surfactant for removal of phenol from waste water by emulsionliquid membrane, Journal of Hazardous Materials. $160: 582-588$.

Molva, M., 2004, Removal of Phenol from Indistrial Wastewaters Using
Lignitic Coals, Thesis, Immir Institute of Technology Izmir, Turkey.

Nghiem, L. D., Mornane, P., Potter, I. D., Perera, J. M. Cattrall, R. W. and Kolev, S. D., 2006, Extraction and Transport of Metal Ions and Small Organic Compounds Using Polymer Inchuston Membranes (PLMs) : Review, J. Membr. Sci. $281,7-41$.

Setyowati, L., 1998, Pengarih Penambahan Divinl Bensena(DVB) pada Kopolimerisasi Kationik Eugenol-DIB dan Sifat Pertukaran Kation Kopoltgaramnya, Tesis, Kimia Universitas Gadjah Mada, Yogyakarta.

Silverstein, Bassler, and Morril, 1984, Penyidikan Spektrometrik Senjawwa Organik, odisi 4, Alih bahasa Hartomo, A. J., dan Purba, A. V., Penerbit Erlangga, Jakarta.

Sun, H, Hankins, N. P, Azzopardi, BJ., Hilal, N., and Almeida, C. A. P., 2008. A Pilos-plant Study of the Adsorptrve Micellar Flocculation Process : Optimum Design and Operation, Puri. Technol., 62(2), $273-280$.

Tayeb, R., Fontas, C., Dhahbi, M., Tingry, S., Seta, P., Cd (II) transpor across supported liquid membranes (SLM) and polymeric plasticizedmembranes (PPM) mediated by Lasalocid A, Scp. Purif. Technol 42(2) (2005) 189-193

Titus, AMM, Nindi. MM., 2006, Supported liquid membrane extraction od 178-estradiol and its metabolism in a variety of biological matrices, Afric J Biotech5 : 1827 1835 